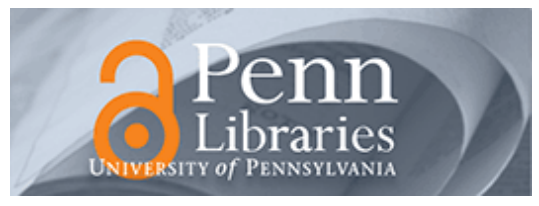

University of Pennsylvania

ScholarlyCommons

Accounting Papers

Wharton Faculty Research

$1-2003$

\title{
Market Valuations in the New Economy: An Investigation of What Has Changed
}

John E. Core

Wayne R. Guay

University of Pennsylvania

Andrew Van Buskirk

Follow this and additional works at: https://repository.upenn.edu/accounting_papers

Part of the Accounting Commons

\section{Recommended Citation}

Core, J. E., Guay, W. R., \& Van Buskirk, A. (2003). Market Valuations in the New Economy: An Investigation of What Has Changed. Journal of Accounting and Economics, 34 (1-3), 43-67. http://dx.doi.org/10.1016/ S0165-4101(02)00087-3

This paper is posted at ScholarlyCommons. https://repository.upenn.edu/accounting_papers/128

For more information, please contact repository@pobox.upenn.edu. 


\title{
Market Valuations in the New Economy: An Investigation of What Has Changed
}

\begin{abstract}
We find mixed support for the hypothesis that a "New Economy" subperiod occurred in the late 1990s in which the relation between equity value and traditional financial variables differs from previous periods. We examine a regression model of equity value on financial variables over 25 years for a broad firm sample and for firm subsamples thought to be emblematic of the New Economy. We find the regression model's explanatory power declined in the New Economy subperiod for all firm subsamples. However, for all subsamples, the regression model's structure during the New Economy subperiod is not unusual compared to other subperiods.
\end{abstract}

Keywords

capital market, equity valuation, new economy

Disciplines

Accounting 


\section{Market Valuation in the New Economy: An Investigation of What Has Changed'}

Article in SSRN Electronic Journal · February 2003

DOI: 10.1016/S0165-4101(02)00087-3

CITATIONS

157

3 authors:

\section{John Core}

Massachusetts Institute of Technology

45 PUBLICATIONS $\quad 6,725$ CITATIONS

SEE PROFILE

Andrew Van Buskirk

The Ohio State University

11 PUBLICATIONS 372 CITATIONS

SEE PROFILE
READS

150
Wayne Guay

University of Pennsylvania

54 PUBLICATIONS $\quad 6,632$ CITATIONS

SEE PROFILE 


\title{
MARKeT VALUATIONS IN THE NEW ECONOMY: AN INVESTIGATION OF WHAT HAS CHANGED
}

\author{
John E. Core \\ The Wharton School \\ University of Pennsylvania \\ 2400 Steinberg-Dietrich Hall \\ Philadelphia, PA 19104-6365 \\ email: jcore@wharton.upenn.edu \\ phone: (215) 898-4821 \\ fax: (215) 573-2054 \\ Wayne R. Guay* \\ The Wharton School \\ University of Pennsylvania \\ 2400 Steinberg-Dietrich Hall \\ Philadelphia, PA 19104-6365 \\ email: guay@wharton.upenn.edu \\ phone: (215) 898-7775 \\ fax: (215) 573-2054 \\ Andrew Van Buskirk \\ The Wharton School \\ University of Pennsylvania \\ 2400 Steinberg-Dietrich Hall \\ Philadelphia, PA 19104-6365 \\ email: vanbuskirk@wharton.upenn.edu \\ phone: (215) 898-6944 \\ fax: (215) 573-2054
}

Current draft: June 2001

\footnotetext{
*Corresponding author. We appreciate helpful comments from Phil Berger, Brian Bushee, John Hand, S.P. Kothari, David Larcker, Rick Lambert, Christian Leuz, Joshua Livnat, Tom Lys (editor), Catherine Schrand, Paul Zarowin, an anonymous referee, and seminar participants at New York University, Rutgers University, the University of North Carolina, and the Wharton School. We gratefully acknowledge the financial support of the Wharton School. Van Buskirk also gratefully acknowledges the financial support of the Deloitte \& Touche Foundation.
} 


\title{
MARKet VALUATIONS IN THE NeW ECONOMY: AN INVESTigation OF What Has Changed
}

\begin{abstract}
The acceleration of globalization combined with rapid advances in technology and the growing importance of the Internet have led many researchers and practitioners to suggest that a "New Economy" has evolved in which equity valuation is different than in previous periods. We examine the explanatory power and stability of a regression model of equity value on traditional financial variables for a broad sample of firms over the past 25 years and investigate how equity valuation has changed in the recent New Economy sub-period. We also examine subsamples of high-technology firms, young firms, and young firms with losses that are thought to be emblematic of the New Economy. We find that the explanatory power of the regression model declined in recent years for all subsamples of firms. However, for all subsamples of firms, we find that the structure of the regression model is quite stable during the New Economy subperiod, as compared to other sub-periods. Together, these results suggest that traditional explanatory variables of equity value remain applicable to firms in the New Economy subperiod, but that there is greater variation remaining to be explained by uncorrelated omitted factors.
\end{abstract}

JEL Classifications: G1, M4 


\section{Introduction}

Equity valuation is one of the most widely researched topics in accounting and finance. A large empirical literature documents the ability of financial variables such as cash flows, income, and balance sheet items to explain equity values. However, in recent years, the traditional relations between financial variables and equity value have been called into question. The acceleration of globalization combined with rapid advances in technology and the growing importance of the Internet have led many researchers and practitioners to suggest that these developments triggered a "New Economy Period" (NEP, hereafter) in the latter half of the 1990s in which equity valuation is different than in previous periods. Although few would argue that equity values no longer reflect expectations about discounted cash flows, there appears to be a widespread belief that accounting variables now play a very different and/or less important role as proxies for expectations about future cash flows.

This paper explores whether, and to what extent, traditional proxies for future cash flows are relevant for explaining equity values of firms operating in the NEP. In contrast to other studies of NEP equity valuation such as Hand (2000), Demers and Lev (2000), and Trueman, Wong, and Zhang (2000), our analysis does not focus exclusively on Internet-related firms. Similar to Amir and Lev's (1996) study of wireless communications firms from 1988-1993, studies of Internet firms observe that traditional proxies for future cash flows do not seem to apply to a specific sample of firms under investigation in a specific time-period, and attempt to fit specialized empirical models to this specialized sample. Instead, we examine the ability of traditional financial variables to explain equity valuation in broad samples of firms over a long time period and assume, 
under our null hypothesis, that these variables are applicable to firms in all time periods. We evaluate our valuation framework not only based on its in-sample fit, but also based on its out-of-sample fit or predictive ability. Under the alternative hypothesis, the relevant variables that explain equity value differ across time periods for some or all firms. Our tests are aimed at determining how the relations between financial information and equity values have changed in recent years, and whether these changes are more unusual than historical changes in these relations. A useful mental exercise that illustrates our approach is to ask the following question: Based on historical relations between financial variables and equity value, in what ways does the NEP stand out as an unusual subperiod?

Using a broad sample of 103,684 firm-year observations between 1975 and 1999, we estimate the cross-sectional relation between equity value and firm-level financial information. To uncover unique aspects of equity values in the NEP, we examine differences in the fit of this regression model during recent years compared to earlier years. We focus on two primary aspects of change in equity value characteristics: (i) whether the NEP is characterized by an unusual reduction in the power of traditional financial variables to explain equity value, and (ii) whether the NEP is characterized by an unusual change in the regression coefficients that map these explanatory variables into equity value. We examine changes in this regression framework for both a broad sample of firms and for subsamples of high-technology firms, young firms, and young firms with losses that have characteristics more commonly associated with the distinctive features of the NEP. 
We find mixed results for our alternative hypothesis that the NEP is characterized by significant changes in the relation between equity values and traditional explanatory variables. On the one hand, the in-sample explanatory power of the traditional explanatory variables is lower in the NEP for all of our subsamples, and this result is robust to controlling for trends in explanatory power over time. On the other hand, we find that the regression coefficients that map financial variables into equity value are surprisingly stable in recent years. Specifically, our tests reveal that out-of-sample regression coefficients fit valuations in the NEP relatively well compared to the fitted valuation errors from earlier sub-periods. This finding holds for the full sample of firms as well as for subsamples of high-technology firms, young firms, and young firms with losses. Together, these results suggest that traditional explanatory variables of equity value remain applicable to firms in the NEP, but that there is greater variation remaining to be explained by uncorrelated omitted factors. 1

While our study shares some common methodology and a common interest in the usefulness of financial information in explaining firm values, our research question and design differ from studies such as Collins, Maydew and Weiss (1997), Brown, Lo and Lys (1999), Francis and Schipper (1999), and Lev and Zarowin (1999) that examine a general trend in the value relevance of accounting information over time. In contrast to these studies, we make no prediction on the trend in explanatory power prior to the NEP. Instead, we examine the data for a shift in financial information's ability to explain firm valuation during the NEP, and a shift in the ability of prior periods' coefficients to fit out-

\footnotetext{
${ }^{1}$ Our finding of greater unexplained variation around a stable relation between equity value and traditional financial variables is similar in spirit to the Francis and Schipper (1999, p. 341) argument that increases in volatility could reduce explained variation even though there is no change in the properties of accounting information.
} 
of-sample NEP data. Finally, in addition to current period earnings and book value, our set of explanatory variables includes proxies for expected growth in profitability.

The next section provides background on the NEP. We develop our hypothesis in the third section and describe our explanatory variables for equity value in Section 4. Section 5 describes our data. We report our empirical results in Section 6 and conclude with Section 7.

\section{Background}

Stock returns and market valuations during the past several years have been higher than historical averages. Fama and French (2000) document an average real return on the S\&P Index of $9.13 \%$ per year over the period 1872-1999. In contrast, the average real annual return on the value-weighted CRSP index is $24.4 \%$ (compounded) from 19951999. Consistent with these returns outpacing underlying earnings growth, Shiller (2000) shows that, as of January 2000, the S\&P composite index had an adjusted Price/Earnings ratio (where earnings is the moving average of the prior ten years of earnings) greater than that in 1901, 1929, and 1966, the previous three largest ratios since 1881. Smithers and Wright (2000) examine a market-wide version of Tobin's $Q$ (Value of Stock Market/Corporate Net Worth) and document that as of the end of 1998, relative valuations were higher than at any other time in the $20^{\text {th }}$ century.

In addition to large returns and high valuations, there is evidence of increased productivity during the late 1990s. For example, the growth rate of non-farm, nonhousing output averaged $4.90 \%$ during the period $1995-1999$, compared to rates of $3.14 \%$ and $2.75 \%$ for the periods 1913-1972 and 1972-1995, respectively (Gordon, 2000). Drivers of this growth rate include the declining price of computing power and large 
investments in information technology and modern manufacturing facilities that benefit from information technology. For example, "at the end of 1995 there was an acceleration of the rate of price change in computer hardware (including peripherals) from an average rate of -14.7 percent during 1987-1995 to an average rate of -31.2 percent during 19961999" (Gordon, 2000, p. 50).

The combination of these economic factors has prompted considerable speculation about the existence of a "New Economy," where increases in globalization and information technology fuel a surge in productivity that accelerates the rate at which the economy may grow without adverse effects. The changing nature of the business environment, combined with high stock valuations, has led many to suggest that the relation between historical financial data and equity prices has changed. However, it is important to note that in any pooled cross-section and time-series with uncertainty, one will observe realized returns and growth rates over short periods that differ from longterm averages. Moreover, within any sub-period certain industry subsectors will have valuation characteristics that differ from the norm in other periods. Therefore, the question of whether a change has occurred in the relation between equity values and traditional explanatory variables cannot be answered by simply observing that equity valuations appear unusual in recent years, or that equity valuations within certain industries seem unusual.

The Internet is thought to be emblematic of the New Economy, and it is sometimes assumed that these firms are particularly difficult to value. The apparently unusual equity valuations for Internet-related stocks have prompted several researchers to explore the relation between Internet firm valuations and firm characteristics, both 
financial and non-financial. For example, Rajgopal, Kotha, and Venkatachalam (2000), Trueman, et al. (2000), and Demers and Lev (2000) investigate the relation between Internet firm valuations and both financial information (e.g., earnings and book value) and non-financial information (e.g., page views). Implicit in this search for the "value drivers" of Internet valuations is an assumption that the explanatory variables underlying an Internet firm's valuation are different from the current or historical variables that explain value for other firms. However, because these studies examine the in-sample fit of various explanatory variables, the coefficients that fit the data well in one period do not necessarily fit well in other periods (e.g., Demers and Lev, 2000).

As illustrated by the following quotation from the May 12, 2001 issue of the Economist, the term "New Economy" is used both to denote the entire economy in the late 1990s as it was thought to be transformed by information technology, and more narrowly and more commonly, the industry sector of firms which produce and might benefit most directly from this information technology:

The most important aspect of the new economy was never the shift to high-tech industries; it was the way in which IT [information technology] could improve the efficiency of old-economy firms.

Consistent with the focus of Gordon (2000), who notes that most of the productivity growth in the "New Economy" was concentrated in the durable goods manufacturing sector, and consistent with our maintained hypothesis that any industry may appear unusual in any period, we refer to the $1996-1999$ period as the New Economy Period (NEP) and test for temporal differences across broad industry sectors. 


\section{Hypothesis development}

For a broad sample of firms, we investigate whether the relation between equity value and explanatory variables in the NEP is different from the historical relations. We estimate a cross-sectional regression model of equity valuation, described in Section 4, that incorporates firm-level financial information on profitability, size, and proxies for expected earnings growth. Because there is little ex ante guidance with respect to how the relation between equity values and explanatory variables differs in the NEP, we focus on two primary dimensions of change: (i) whether the NEP is characterized by an unusual reduction in the explanatory power of variables traditionally used to explain equity value, and (ii) whether the NEP is characterized by an unusual change in the regression coefficients that map these traditional variables into equity value. Because the economic conditions that exist in the NEP are sometimes thought to affect certain types of firms to a relatively greater extent, we conduct all of our tests on a broad sample of firms as well as on subsamples of high-technology firms, young firms, and young firms with losses.

We explore whether the NEP is characterized by an unusual reduction in the ability of traditional financial variables to explain equity values by comparing the explanatory power of the regression model (measured by $\mathrm{R}^{2}$ ) during the NEP with the explanatory power during prior periods. Note that a gradual decline in $\mathrm{R}^{2}$ over our 25 year sample period would not be consistent with the emergence of a NEP in the late 1990s, whereas a sharp decline in $\mathrm{R}^{2}$ in later part of the sample period would be suggestive of a NEP.

By itself, evidence on the regression model's explanatory power paints an incomplete picture of equity values over time. The structure of the regression model can 
change over time even when explanatory power is relatively constant. Similarly, changes in explanatory power do not necessarily imply that the coefficients in the regression model have changed (e.g., increased unexplained variation in firm valuations can decrease explanatory power without altering the mapping between explanatory variables and firm value). To explore changes in the regression model's structure over time, we examine whether the NEP is characterized by a marked shift in the model's stability relative to the shifts that occurred in earlier periods. We compare subperiods by evaluating the reduction in explanatory power when we use out-of-sample period rather than in-sample period regression coefficients to explain variation in firm values.

We note two caveats in our analysis. First, our tests are silent on the question of whether or not the market "correctly" values stocks within a given time period. Second, the inferences in this study, like any study of market valuation in the NEP, potentially suffer from a sample selection bias. This problem arises because the motivation for making the NEP a focal point in this investigation is based, at least in part, on the unusually high stock returns and market valuations during this time period (i.e., the sample selection is based on a variant of our dependent variable). This selection issue can bias our findings in favor of finding significant differences in the valuation characteristics of NEP firms. That is, it is likely to be relatively easier to identify unusual valuation characteristics within a sample of firms that are selected at least in part based on popular conceptions about the unusual nature of their market valuations. Although this issue is common to all NEP valuation research, we hope to minimize this problem by analyzing a broad sample of firms, instead of focusing exclusively on a new, specialized industry that appears to have extreme valuation characteristics (e.g., Internet firms). In addition, to 
avoid look-back bias in our model, we choose our explanatory variables to be financial variables traditionally used to explain equity value.

\section{Empirical model of firm value}

In this section, we develop a regression model that relates equity value to financial variables that are expected to be associated with current and expected future cash flows. Our objective is to select explanatory variables that have widespread theoretical and empirical support, and are therefore expected to be robust over time. We do not attempt to maximize the model's fit in any particular time period by constructing stylized models with time-period-specific or industry-specific explanatory variables. In contrast to our objective, stylized models are unlikely to have robust predictive power over time.

Our regression model has theoretical and empirical antecedents in both the accounting and the finance literature. Specifically, we model the ratio of the market value of equity to the book value of equity as a function of profitability, size, and proxies for expected earnings growth. Our use of market value of equity scaled by book value of equity as a measure of firm value is consistent with much of the empirical finance and accounting valuation research.

One intellectual antecedent for our work is the large literature in accounting that implicitly or explicitly follows Ohlson (1995), and models the market value of equity as a function of the book value of equity, current earnings, and proxies for expected earnings growth (e.g., Collins et al., 1997; Dechow, Hutton, and Sloan, 1999). Following other researchers, we deflate this model by the book value of equity, which gives the earnings variable the interpretation of a return on book equity (Palepu, Bernard, and Healy, 1996; 
Beaver, 1999). Deflating by book value of equity also addresses potential problems with heteroscedasticity and the intertemporal stability of the model's coefficients and explanatory power (Brown, Lo, and Lys, 1999)..$^{\text {2 }}$ Further, several recent studies of valuation in the NEP, such as Rajgopal et al. (2000) and Trueman et al. (2000), use market-to-book equity as their measure of firm value.

A large literature in finance measures firm value using proxies for Tobin's $Q$ ratio (Tobin, 1969). The market-to-book equity ratio is highly correlated with Tobin's $Q$ metric of relative firm valuation ${ }^{3}$ Thus, another intellectual antecedent for our model is the literature that seeks to explain Tobin's $Q$ as a function of proxies for profitability, growth opportunities, and firm size (e.g., Lindenberg and Ross, 1981; Morck, Shleifer, and Vishny, 1988; Himmelberg, Hubbard, and Palia, 1999). In sensitivity analysis, we verify that our results are not sensitive to using market value of assets scaled by book value of assets as an alternative measure of firm value.

Our explanatory variables include net income before extraordinary items (scaled by book value of equity) as a proxy for current firm profitability. Because prior literature documents differences in the valuation of losses and profits (e.g., Hayn, 1995; Basu, 1997; Collins et al., 1997), we allow for different slope coefficients on profit and loss years.

We also include proxies for growth opportunities and expected growth in earnings. Collins, Kothari, Shanken and Sloan (1994) document that including growth proxies in a regression model of equity value mitigates the loss in explanatory power that

\footnotetext{
${ }^{2}$ Our inference is unaffected if we instead deflate by the lagged market value of equity as suggested in Brown et al. (1999).

${ }^{3}$ Within our sample, the market-to-book equity ratio has a 0.96 rank correlation with the market-to-book assets ratio, which is often used as a proxy for Tobin's $Q$.
} 
results from market prices leading accounting information (i.e., lack of timeliness in accounting information). Similar to Morck et al. (1988) and Demers and Lev (2000), we include Advertising expenditures and Research and Development (R\&D) expenditures (both scaled by book value of equity) to capture expected growth in future earnings due to investments in intangible assets. While studies that examine Tobin's $Q$ find a robust positive association between $\mathrm{R} \& \mathrm{D}$ and $Q$, there is no consistent positive association between $Q$ and advertising expenditures (e.g., Himmelberg et al., 1999, show a negative association, while most other studies show a positive association). We also include capital expenditures (scaled by book value of equity) to capture expected growth in earnings due to new investments in tangible assets. Himmelberg et al. (1999) find that this variable has a positive association with $Q$. We include sales growth over the previous year (change in sales scaled by book value of equity) as an additional proxy for expected earnings growth. ${ }^{\natural}$ To avoid a potential bias caused by excluding young firms that do not have sales data available from the previous year, we set sales growth equal to zero for firm years with missing data, and include a dummy variable equal to one if sales growth data is unavailable, and equal to zero otherwise. We predict positive coefficients on all of our growth proxies.

Our use of a dependent variable that is scaled by book value suggests that the inverse of book value should be included in the regression. This variable can be motivated from both the Ohlson model perspective and the Tobin's Q model perspective. For example, consider the unscaled version of our model as an empirical application of the Ohlson model where the regression includes an intercept, book value of equity, and

\footnotetext{
${ }^{4}$ We do not use analysts' forecasts as a proxy for growth because these forecasts are not available for the early years of our sample and for much of our sample in the later years.
} 
the other explanatory variables. Scaling by book value of equity yields a regression model that includes the inverse of book value and where the intercept can be interpreted as the coefficient on book value in the unscaled model (e.g., Trueman et al., 2000). In the literature modeling Tobin's Q, researchers generally find an inverse relation between $Q$ and size (e.g., McConnell and Servaes, 1990). Therefore, the inverse of book value also serves as a control for size and we expect a positive coefficient on this variable.

The regression model is:

$$
\begin{aligned}
M V E / B V E= & \alpha_{0}+\alpha_{1}(1 / B V E)+\alpha_{2}\left(P O S \_N I / B V E\right)+\alpha_{3}\left(N E G \_N I / B V E\right)+ \\
& \alpha_{4}(R N D / B V E)+\alpha_{5}(A D V E R T / B V E)+\alpha_{6}\left(C A P \_E X / B V E\right)+ \\
& \alpha_{7}\left(S A L E S \_G R / B V E\right)+\alpha_{8} S G \_M I S S+\varepsilon
\end{aligned}
$$

\begin{tabular}{|c|c|}
\hline$E=$ & $\begin{array}{l}\text { Market value of equity (obtained from CRSP) and measured } \\
\text { four months following the fiscal year-end) }\end{array}$ \\
\hline BVE & Book value of equity (Compustat item \#60) \\
\hline POS & $\begin{array}{l}\text { Income Before Extraordinary Items if Net Income Before } \\
\text { Items }>0,0 \text { otherwise (Compustat item \#18) }\end{array}$ \\
\hline NEG_NI = & $\begin{array}{l}\text { Net Income Before Extraordinary Items if Net Income Before } \\
\text { Ex. Items } \leq 0,0 \text { otherwise (Compustat item \#18) }\end{array}$ \\
\hline ND & $\mathrm{R} \& \mathrm{D}$ \\
\hline ADVERT $=$ & item \#4 \\
\hline AP_EX = & Capit: \\
\hline SALĒES_GR & $\begin{array}{l}\text { One year change in real sales dollars (Compustat item \#12, } \\
\text { adjusted for changes in CPI) if available, and zero otherwise }\end{array}$ \\
\hline G_MIS & $\begin{array}{l}\text { Dummy variable equal to one if sales growth data is } \\
\text { unavailable and zero otherwise }\end{array}$ \\
\hline
\end{tabular}

Where:

All variables except market value of equity are measured at the end of the fiscal year. Market value of equity is measured four months after the end of the fiscal year (i.e., at April 30 for a firm with December fiscal year-end) to ensure that the financial data have become publicly available. All variables except SG_MISS are adjusted to constant 1983 dollars using the CPI deflator (The only variables directly affected by this adjustment are 1/BVE and SALES_GR/BVE, as the adjustment does not affect the 
remaining variables, which are ratios). Consistent with prior research, such as Morck et al. (1988), we set R\&D, Advertising, and Capital expenditures equal to zero when their values are missing.

One concern with comparing the explanatory power and stability of our regression model over a 25-year period is that the composition of the sample firms changes over time. For example, if firms in high-technology industries are valued differently than other firms, a shift in the full sample toward high-technology firms could lead to the mistaken conclusion that the explanatory variables for equity value have changed. To mitigate this concern, we examine separately two broad subsamples of firms that are likely to be of interest to those investigating valuation in the NEP: "Young" firms (relatively few years in existence) and firms operating in a "Hightechnology" industry. We also separately examine Young firms that are not profitable. Examining the Young and High-technology firms separately also allows us explore the common belief that valuation characteristics have changed in the NEP for some groups of firms but not others.

The valuation of young firms and high-technology firms is likely to be influenced by many informational issues that are less important for older, more established firms. The valuation of high-technology firms is influenced by factors such as the prevalence of intangible assets and the importance of future growth that effect other firms to a lesser extent. We use Francis and Schipper's (1999) definition of High-technology firms. They define High-technology industries based on previous research as well as their priors about whether firms in the industry are likely to have significant unrecorded intangible assets. Examples of industries categorized as High-technology include computer hardware and 
software, pharmaceuticals, electronic equipment and telecommunications. We recognize that this classification scheme does not perfectly categorize high-technology firms over time (e.g., an industry that is widely considered high-technology in the later part of the sample period may not be widely considered high-technology in the earlier part of the sample, raising the potential for a look-back bias). To the extent that the errors in classification vary over time, our tests will be biased in favor of finding significant changes in the regression model over the sample period.

Similar to High-technology firms, we expect that young firms have informational problems that influence valuation. For example, because young firms have a short track record and have had little time to establish credible disclosure patterns, forecasts of future cash flows are likely to be characterized by considerable uncertainty (e.g., Lang, 1991). We categorize a firm-year observation as "Young" if its first trading date is less than two years before the date on which we measure the firm's market value (e.g. if the firm's fiscal-year end is June 30, 1975, we measure its market value on October 31, 1975, and we consider it to be Young if it started trading on or after November 1, 1973). We use the CRSP beginning date to measure the date that the firm began trading. Ideally we would measure firm age as the time since its founding. To the extent that firms in recent years wait fewer years before coming public (e.g., there is less time between their foundation date and IPO date), these firms will have less of an operating history than young firms in the earlier part of the sample. In this case, the firms we define as Young during the later part of the sample period will be systematically different from the firms defined as Young during the earlier sample years. Again, to the extent that Young firm 
characteristics have changed over time, our tests will be biased in favor of finding significant changes in the regression model over the sample period.

\section{Data}

We obtain a sample of non-financial firms from Compustat and CRSP. For convenience and in order to maximize our sample size, we define a firm-year consistent with Compustat data conventions, e.g., the year 1999 corresponds to firms with fiscal years ending between June 1999 and May 2000. We restrict the sample to begin in 1975 to include NASDAQ firms over the full sample period and lessen concerns about shifts in market structure over the 25-year sample period. ${ }^{\mathrm{G}}$ After deleting firms with incomplete data from CRSP or Compustat, we start with an initial sample of 109,636 firm-year observations from 1975 through 1999. Our requirement that firms have positive book value reduces this sample to 104,704 firms.

Following Collins et al. (1997), we mitigate the effect of extreme values of the dependent variable by deleting observations in the top and bottom one-half percent of market value to book value (by year and by subsample). This deletion procedure results in a final full sample size of 103,684 firm-year observations from 1975-1999. After deleting extreme observations, we obtain a total of 22,557 and 16,865 firm-years in our High-technology and Young subsamples, respectively. The number of firms classified as neither High technology nor Young (the "Neither" subsample, hereafter) is 69,354. The number of firms in the three subsamples sums to more than 103,684 because a fraction of

\footnotetext{
${ }^{5}$ We use 1975 as our earliest annual Compustat data year even though CRSP first includes NASDAQ data in December 1972. The reason is that our Young firm subsample (described below) is defined to be firms trading for less than two years. If we included Compustat year 1974, we would not be able to determine if NASDAQ firms with, for example, June 1974 fiscal year-ends had been trading for two years, because their beginning date on CRSP is December 1972.
} 
the firms is classified as both High-technology and Young. We mitigate the effects of outliers in the independent variables by setting extreme values of the independent variables equal to the values at the $1 \%$ and $99 \%$ levels (by year and by subsample). We winsorize these values instead of deleting them to conserve data. Winsorizing and deleting extreme values by year and subsample ensures that an equal fraction of observations are winsorized or removed from each data year and from each subsample in each data year.

In Table 1, we present descriptive statistics for the annual number of firms, average market-to-book ratio, and coefficient of variation (CV) of the market-to-book ratio for each of our subsamples. The firms categorized as High Technology and Young have increased steadily over the sample period, both in number and as a fraction of the overall sample. Panel A of Table 1 shows that the mean market-to-book equity ratio increases over the sample period, and in Panel B of Table 1 this temporal increase is confirmed by a regression analysis that finds a significant positive coefficient on a time trend variable. This finding is consistent with academic research that finds financial accounting has become more conservative and less able to capture intangible assets over time, and is also consistent with popular notions that market valuations have risen in recent years.

\footnotetext{
${ }^{6}$ Deleting firms with negative book values removes a greater percentage of Young (7.4\%) and Hightechnology firms (5.5\%) than it does Neither firms (3.8\%). We perform sensitivity tests to ensure that our inferences are not affected either by our deletion of firms with negative book value or by our procedures to mitigate the influence of extreme observations. To check the robustness of our results, we re-estimate Equation (1) using both market value scaled by lag market value and market value of assets scaled by book value of assets as the dependent variable (thereby eliminating the need to remove firm-years with negative book value) and do not remove or winsorize extreme observations in the dependent or independent variables. Although the explanatory power of the model and the precision of our tests is reduced, the tenor of the results is unchanged. Specifically, the documented similarities and differences between the valuation characteristics of firms in the NEP and firms in other periods remain unchanged.
} 
Although market-to-book equity increases over time within the full sample of firms, the increase is greater for the High-technology and Young firm subsamples, as shown by the magnitude of the regression coefficients in Panel B. Although there are large increases in the market-to-book ratio in 1998 and 1999, untabulated regression analysis that includes a dummy variable for the 1996-1999 period indicates that this variable is not significantly different from zero after controlling for the time trend. Finally, Table 1 shows that the coefficient of variation (sample standard deviation divided by sample mean) of the market-to-book ratio has increased significantly over the sample period. One objective of the tests that follow is to identify how much of this additional cross-sectional variation in firm value is explained by variation in traditional explanatory variables, and how much, if any, is due to other factors that are uncorrelated with the variables in our regression model.

Throughout our analysis, we entertain the possibility that a shift in the relation between firm value and our explanatory variables may have occurred at any time over the sample period. That is, we allow the data to inform us as to whether valuations in the NEP are unusual. This approach reduces the likelihood that we make a Type I inference error (i.e., rejecting the null hypothesis that the NEP is not unusual when it is true). With respect to constructing tests about the nature of valuations in the NEP, it is difficult for us to define precisely when the "NEP" began. We note that recent comments from the Vice Chairman of the Federal Reserve Board suggest that the economic factors denoting a NEP significantly accelerated around the year 1995 (Vice Chairman Ferguson, Conversations with Leaders of the "New Economy", 5/9/00). In addition, 1995 is the year Netscape Communications, the provider of the original Internet browser, went public. We 
use the four-year period from 1996-1999 as corresponding to the NEP and compare this period to other four-year periods in our sample. However, all of our results are robust to using a longer (five-year) or shorter (three-year) time period, or to defining 1995-1998 as the NEP.

\section{Results}

Table 2 reports aggregated by-year results for our regression model over the full sample period. Because of concerns about cross-sectional correlation in valuations, we estimate the regressions by year and aggregate the coefficients as in Fama and MacBeth (1973). The coefficients reported in Table 2 are the mean coefficients from the by-year regressions. Because the estimated coefficients are likely to exhibit positive autocorrelation, we compute t-statistics using adjusted standard errors. We follow Kothari and Zimmerman (1995, p. 170), and correct the standard errors using the Newey and West (1987) adjustment, with six lags, for serial dependence in the coefficients. We also report the number of coefficients (out of 25) that are positive in the by-year regressions.

In the full sample (Column 1), the signs of the estimated coefficients are consistent with prior research, and, with the exception of advertising expense, all explanatory variables have significant coefficients. Further, with the exception of advertising expense, all explanatory variables have a consistent relation with firm value, with coefficients of the same sign in at least 19 of the 25 sample years. The mean $\mathrm{R}^{2}$ is $35 \%$. There are two somewhat surprising results. First, the coefficient on earnings in loss years is significantly negative in all but the Young firm subsample. This finding indicates that after controlling for the other explanatory variables, large losses precede higher future cash flows than small losses, possibly due to the transitory nature of large losses. 
The significant negative coefficient on negative earnings is consistent with the results in Collins et al. (1997), although they use a different scaling variable on equity value..$^{7}$ The second coefficient that appears somewhat unusual is the intercept, which is not significantly greater than zero, in contrast to what one might expect given its interpretation as the coefficient on book value in an undeflated regression. In untabulated results, we find that the intercept is consistently and significantly positive when the regression only includes an intercept, 1/BVE and the earnings variables. However, the introduction of the additional explanatory variables can change the sign of the intercept (for an example, see Trueman et al., 2000).

In Columns 2, 3 and 4, we report regression results for the High-technology, Young and Neither subsamples. The coefficients are all of the same sign as those in the full sample, and the overall regression results suggest that our regression model is robust over time and across subsamples of firms. However, untabulated tests strongly reject that the coefficients across the subsamples are equal, indicating that these groups have different valuation characteristics. Advertising expense is not significant in the Hightechnology subsample, and loss, advertising expense, and sales growth are not significant in the Young subsample.

\subsection{Change in explanatory power}

In Table 3, we examine the pattern of explanatory power for our regression model over time. A lower level of explanatory power in the NEP indicates that the increased mean and cross-sectional variation in value documented in Table 1 serves to increase the unexplained variability of the regression model. However, a stable level of explanatory power suggests that while the level and variation of value in the NEP is greater than

\footnotetext{
${ }^{7}$ We also find a negative coefficient on losses using Tobin's $Q$ as the dependent variable.
} 
earlier periods, these characteristics are well-explained by the explanatory variables in the regression model. Panel A of Table 3 presents $\mathrm{R}^{2}$ results for each of our 25 sample years, and Panel B presents tests of time trends in $\mathrm{R}^{2}$ over the sample period.

For all of the subsamples, the annual $\mathrm{R}^{2}$ for the years 1996 to 1999 is below the median annual $\mathrm{R}^{2}$. In untabulated tests, the average $\mathrm{R}^{2}$ for the period 1996-1999 is significantly lower than the average for the remaining 21 years $(\mathrm{p}$-value of $\mathrm{t}$-test $<0.05)$. However, this inference regarding explanatory power is potentially misleading in light of evidence in Brown et al. (1999) suggesting that $\mathrm{R}^{2}$ has been decreasing over the last four decades. In Panel B of Table 3, we present results when $\mathrm{R}^{2}$ is regressed on a time trend variable, and in Panel $\mathrm{C}$, we present results when $\mathrm{R}^{2}$ is regressed on a time trend variable and the CV of the market-to-book ratio. Consistent with Brown et al. (1999), we find that $\mathrm{R}^{2}$ for the full sample has declined over time, both with and without a control for the coefficient of variation. With respect to the subsamples, the regressions indicate that while $\mathrm{R}^{2}$ has decreased over time for the High technology and Young subsamples, it has not changed over time for the Neither subsample.

In Panel D, we explore the significance of the reduction in $\mathrm{R}^{2}$ during the NEP. We estimate a regression of annual $\mathrm{R}^{2}$ on a time trend variable, an indicator variable equal to one if the year is 1996-1999 and zero otherwise, and the CV of the market-to-book ratio. In the full sample as well as in all of the subsamples, the coefficient on the NEP indicator variable is negative and significant. The negative coefficient on the indicator variable for the 1996-1999 period indicates that the explanatory power of Equation (1) is lower for all of the subsamples during the NEP, after controlling for time trends in explanatory power. 
We obtain qualitatively similar results in Panels C and D if we do not include a control for the CV of the market-to-book ratio.

The high valuations documented in Table 1 , combined with the reduced $\mathrm{R}^{2}$ during the NEP shown in Table 3, support the notion that firm value in the NEP is higher than in previous periods and that it is characterized by a source of variation that is not well captured by our explanatory variables. The reduction in $\mathrm{R}^{2}$ during the NEP suggests that either: (1) firm value in the NEP contains additional unexplained variation that is not correlated with the explanatory variables included in the regression model described by Eq. (1); or (2) one or more of the explanatory variables in our model now contains less information (more error) with respect to firm value (e.g., the coefficients are biased due to the omission of information about the measurement error in the explanatory variables); or both (1) and (2).

\subsection{Coefficient stability}

The tests reported in Table 4 help discriminate between the alternative explanations outlined above for the results in Table 3. Specifically, we explore the temporal stability of the structure underlying Equation (1). If the reduction in $\mathrm{R}^{2}$ reported in Table 3 is due to increased error in one or more of the explanatory variables, the regression coefficients will not be stable over time (i.e., increased error will bias the regression coefficients). An increasing level of coefficient bias results in a temporally unstable model, and suggests that changes in the information content of our explanatory variables (caused by measurement error in these variables that is unrelated to expected future cash flows) likely contributes to the observed reduction in $\mathrm{R}^{2}$ during the NEP. On the other hand, if the coefficients are stable over time, this suggests that a temporally 
consistent amount of information about future cash flows is captured by the explanatory variables. In this case, the reduction in $\mathrm{R}^{2}$ over time is likely due to a source of variation in firm value that is uncorrelated with the explanatory variables (i.e., measurement error in the dependent variable).

We measure coefficient stability by the loss of explanatory power that occurs when we use one period's coefficients to predict valuations in other sample periods. The loss of explanatory power captures the degree to which the prior period's coefficients are different from the contemporaneous OLS coefficients. When the regression model is stable (unstable) across periods there is little (much) prediction error when one period's coefficients are used to predict the next period's valuation.

To see this, consider the prediction error (PE) obtained when one period's valuation $\left(y_{i t+1}\right)$ is predicted by applying another period's set of coefficient estimates $\left(\hat{\beta}_{t}\right)$ to the predicted period's vector of explanatory variables $\left(X_{i t+1}\right)$ :

$$
P E_{i t+1}=y_{i t+1}-X_{i t+1} \hat{\beta}_{t}
$$

Note that the PE can be re-expressed as the sum of the error from the OLS regression plus additional error arising from coefficient differences:

$$
P E_{i t+1}=\left(y_{i t+1}-X_{i t+1} \hat{\beta}_{t+1}\right)+X_{i t+1}\left(\hat{\beta}_{t+1}-\hat{\beta}_{t}\right)=\hat{\varepsilon}_{O L S i t+1}+X_{i t+1}\left(\hat{\beta}_{t+1}-\hat{\beta}_{t}\right)
$$

Defining PSS as the sum of squared PEs defined by Eq. (3) and RSS as the sum of squared OLS residuals ( $\hat{\varepsilon}_{\text {OLSit }+1}$ ), it follows from Eq. (3) that:

$$
(P S S-R S S)=\left(\hat{\beta}_{t+1}-\hat{\beta}_{t}\right)^{\prime} X_{t+1}{ }^{\prime} X_{t+1}\left(\hat{\beta}_{t+1}-\hat{\beta}_{t}\right) .
$$

To compare lack-of-fit across periods, we scale Eq. (4) by SYY, the sum of the squared deviations of the dependent variable from its mean: 


$$
(P S S-R S S) / S Y Y=\left(\hat{\beta}_{t+1}-\hat{\beta}_{t}\right)^{\prime} X_{t+1}{ }^{\prime} X_{t+1}\left(\hat{\beta}_{t+1}-\hat{\beta}_{t}\right) / \sum\left(y_{i t+1}-\bar{y}_{t+1}\right)^{2},
$$

and term the resulting expression the "loss in coefficient explanatory power." Because the in-sample $\mathrm{R}^{2}$ is equal to (1-RSS/SYY), our scaled measure can also be interpreted as the loss in explanatory power from the out-of-sample fit: (PSS - RSS)/SYY = $R_{O L S}^{2}-R_{P R E D}^{2}$

From Eq. (5), it follows that the loss in coefficient explanatory power is driven by the difference between the in-sample coefficients and the out-of-sample coefficients. For example, if the in-sample and out-of-sample coefficients are the same, the loss in coefficient explanatory power is zero. In this case, any difference in the in-sample $\mathrm{R}^{2}$ between the two periods is due to differences in unexplained variation in the dependent variable between periods. In contrast, large differences in the in-sample and out-ofsample coefficients indicate structural changes in the regression model, and suggests that a difference in the in-sample $\mathrm{R}^{2}$ between two periods is due to differences in the amount of measurement error in the independent variables.

In Table 4, we provide tests for model stability. In Panel A, we report results in which each 4-year period is predicted using estimated coefficients from the preceding 4year period. In Panel B, we report results in which each 4-year period is predicted using estimated coefficients from the twenty-one firm-years that are not in the predicted period. In Panel A, we do not have a complete four-year period to make predictions prior to the 1979-1982 period (i.e. the period 1978-1981 is preceded by the three-year period 19751977), and we therefore report results for the 18 periods beginning with the period 19791982. We do not face this restriction in Panel B (e.g., we can predict the 1978-1981 period with 21 years of data, consisting of the three-year period 1975-1977 and the 18- 
year period 1982-1999), so we report results for the 21 years beginning with the period 1975-1978. In each panel, the four-year predicted period is indicated in the first column. For the full sample and for each subsample, we present both the loss in coefficient explanatory power and the ranked losses in explanatory power from smallest loss $(1=$ smallest loss in explanatory power) to largest loss $(18=$ largest loss in explanatory power in Panel A and $22=$ largest loss in explanatory power in Panel B).

In all of the subsamples, the number of firm-year observations varies over time. To give each year equal weight in our regressions, we estimate all regressions in Table 4 by weighted least squares, where the weights for each observation in a sample-year are inversely proportional to the number of observations in that year. This weighting procedure avoids biasing our tests in favor of finding that periods with more observations look less unusual. Without the weighting procedure, periods that have more observations (e.g., the NEP) would have a greater influence in the 21-year prediction model, which ceteris paribus would cause these periods to look less unusual than periods with fewer

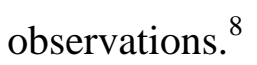

In Panel A, the losses in coefficient explanatory power are comparatively small for the 1996-1999 NEP. For the full sample, and the High-technology and Neither subsamples, the loss in explanatory power for the NEP is smaller than the loss for the median sub-period. The loss for the Young subsample is slightly greater than the median subperiod. These results are consistent with the hypothesis that compared to other

\footnotetext{
${ }^{8}$ As an example of how the weighted least squares procedure removes inference bias in our tests, consider the results for the Young subsample in Panel B of Table 4. The ranked 21-year loss in coefficient explanatory power for the 1996-1999 period is 14 using ordinary least squares compared to a ranking of 17 using weighted least squares.
} 
subperiods, the structure of our equity value regression model in the NEP is not unusually different from the 4-year period preceding the NEP.

The results in Panel B use the considerably longer 21-year prediction period and confirm that the NEP is not characterized by an unusually large change in the equity value regression model. For the Full sample and the Young subsample, the losses in coefficient explanatory power for the 1996-1999 period are greater than the loss for the median subperiod. (We explore the large loss in coefficient explanatory power for the Young subsample in greater detail below.) In contrast, the loss in explanatory power in the High-technology and Neither subsamples during the NEP is slightly less than the loss for the median sub-period. We again emphasize that we obtain the same inference when we use 3-year or 5-year prediction periods. Overall, the results in Table 4 indicate that the in-sample regression coefficients that map explanatory variables into firm value during the NEP are quite similar to the coefficients estimated during the preceding 4 years, and not unusually different from those estimated over the remaining 21 years in the sample period.

A potential concern with our findings in Table 4 is that a portion of the loss in coefficient explanatory power could be driven by macro-economic variation in the level of valuations that is unrelated to our explanatory variables. For example, the 1987-1990 period exhibits a large loss in coefficient explanatory power, and ex post we know that 1987 market values were highly variable around the time of the October 1987 crash for macro-economic reasons that are not clearly related to earnings or growth expectations. This unusual market valuation could result in an unusual intercept for that period that results in a large calculated loss even if the coefficients on the explanatory variables 
remain constant over time. In support of the notion that there is substantial variation in the level of valuations that is unrelated to our explanatory variables, we note that the annual intercepts from the regressions reported in Table 2 vary considerably and, except for the Young firms, increase over time for each of the subsamples. Further, untabulated tests strongly reject that the annual intercepts are equal.

To remove the effects of market-wide fluctuations in firm value over time, we remove the mean of the dependent variable and independent variable for each month-year of our sample. This is equivalent to introducing a month-year fixed effect into our regression model (see Greene, 1997, p. 617). By estimating the regression on the demeaned variables, we assess the loss in coefficient explanatory power for the explanatory variables only, and exclude any loss due to differences in intercepts from one period to another. In untabulated results, we find that the losses in coefficient explanatory power using de-meaned variables are consistently smaller than the losses reported in Table 4. However, the relative 4-year and 21-year rankings for the High-technology and Young firms are unchanged. The rankings for the 21-year losses for the Neither subsample do change substantially: the NEP rank is 3 (compared to 11 in Table 4), and the loss in coefficient explanatory power is well below the median. 9

Based on the loss in coefficient explanatory power rankings shown in both Panels A and B of Table 4, the subsample for which the NEP appears most unusual is the Young

\footnotetext{
${ }^{9}$ As another way of controlling for the effects of market factors, we orthogonalize our variables with respect to the following three macroeconomic factors: (i) yield on the 10-year Treasury bond; (ii) rate of change in the Consumer Price Index; and (iii) change in constant dollar GDP. The frequency of the macroeconomic data is monthly for the yield on the 10-year Treasury bond and the rate of change in the CPI and quarterly for the change in constant dollar GDP. This orthogonalization procedure allows us to interpret coefficients as the partial regression coefficients that would be obtained had the macroeconomic variables been in the model (see Greene, 1997, p. 179-180). When we repeat our Table 5 analysis on these transformed variables, none of our inference in Table 5 is changed.
} 
firms. As noted above, we chose the Young subsample (as well as the High-technology subsample) to isolate groups of firms with informational problems related to valuation. To further explore information problems within the Young subsample, we examine separately the subsample of Young firms that have losses (net income before extraordinary items less than zero). A firm that comes public with a loss is likely to have greater growth opportunities than a profitable firm. In addition, firms that come public with losses are likely to have a shorter operating history than a profitable firm. It is commonly believed that a confounding feature of Internet firm valuation is that most of these newly-public firms have not achieved positive profits (e.g., Trueman et al, 2000). Consistent with our Young, Loss subsample having characteristics similar to an Internet sample, we find that, for data year 1999, we classify as Young, Loss $71 \%$ of the firms out of Hand's (2000) Internet firms for which we can find data. 10 . Examining Young, Loss firms over time, allows us to explore whether historical valuation characteristics of firms broadly similar to Internet firms are unusual in the NEP.

Table 5 contains 4-year and 16-year loss in explanatory power results for the Young, Loss subsample. We restrict our analysis to a sample beginning in 1980 because we have a small number of Young firms, and a particularly small number of Young, Loss firms prior to 1980.1 Compared to the full sample and the High-technology and Young subsamples, the regression coefficients are less stable for the Young, Loss firms, as indicated by the larger mean and median loss in coefficient explanatory power. However,

\footnotetext{
${ }^{10}$ Of 274 firms in Hand's sample, we are able to find 201 firms with non-missing CRSP/Compustat data in 1999, of which 11 are financial firms. Of the remaining 190, 2 have negative book value, and 2 are deleted because of extreme market-to-book ratios (i.e., our deletion procedure retains $98 \%$ of the Internet sample as compared to the $95 \%$ retention rate for our overall sample). This leaves 186 Internet firms in our 1999 sample: 157 are classified as High-technology, 145 are classified as Young, and 132 (71\%) are classified as Young, Loss.
} 
the NEP period exhibits relatively small losses in explanatory power as indicated by the low loss rankings in later periods! 12 Thus, we find that although Young, Loss firms generally exhibit a less stable relation between equity value and explanatory variables in all time periods, the NEP does not stand out as an unusual period. Our finding that the regression coefficients for Young, Loss firms are highly variable over time suggests that it is inappropriate to motivate studies based solely on an unusual mapping of financial data into prices for certain Young, Loss firms in a given time period (e.g., the NEP). Our results suggest that Young, Loss firms' valuation coefficients in one period generally look unusual when compared to other periods, and that they actually look less unusual in the NEP.

In summary, the reduction in $\mathrm{R}^{2}$ during the NEP documented in Table 3 does not appear to be due to increased measurement error in the variables traditionally used to explain equity value. In contrast to the results in Table 4, increased measurement error in the explanatory variables during the NEP would bias the regression coefficients and result in a poor out-of-sample fit when historical regression coefficients are used to predict firm value. Thus, it appears that the reduction in the regression model's explanatory power in the NEP is due to increased unexplained variation in equity values. 13 High technology firms, Young firms, and Young firms with losses generally

\footnotetext{
${ }^{11}$ We obtain the same relative rankings if we use the longer, 21-year time-period, because the losses in the years not included are particularly large.

${ }^{12}$ In untabulated results, we also find that Young firms without losses do not exhibit an unusual loss of coefficient explanatory power in the NEP.

${ }^{13}$ A potential contributing factor to this increased unexplained variation in equity values is the growing complexity in the capital structures of certain types of firms. For example, firms' use of stock options and other convertible securities has increased in recent years, particularly among high growth firms. The exclusion of equity-like securities, such as stock options, from the computation of equity value induces measurement error in regression models designed to test the relation between firm value and explanatory variables (e.g., see Core, Guay and Kothari, 2001).
} 
exhibit a less stable relation between equity value and explanatory variables, but within these subsamples, the NEP does not stand out as an unusual subperiod.

\section{Conclusion}

There have been recent claims that the United States has entered a New Economy Period and that, because of this New Economy, traditional financial variables are not related to firm value in the same way as in prior periods. We study a broad sample of 103,684 firm-year observations from 1975-1999 to investigate whether such claims of a New Economy Period are supported by the data. In addition to the full sample, we analyze subsets of firms that are deemed especially important in the New Economy, namely high-technology firms, young firms, and young, unprofitable firms.

We document that for all subsamples, the level of firm value and cross-sectional variation in firm value increased substantially around the New Economy Period. We find that the ability of traditional financial variables to explain firm value decreased for all subsamples in the NEP. We provide evidence that this decline in explanatory power does not appear to be due to an unstable relation between firm value and traditional financial variables, such as earnings, book value, and growth opportunities. Compared to earlier periods, the relation between firm value and traditional financial variables has remained very stable throughout the 1990's. Overall, our results suggest that traditional explanatory variables of equity value remain applicable to firms in the New Economy sub-period, but that there is greater variation in firm values remaining to be explained by uncorrelated omitted factors. 


\section{References}

Amir, E., Lev, B., 1996. Value-relevance of nonfinancial information: The wireless communications industry. Journal of Accounting \& Economics 22, 3-30.

Basu, S., 1997. The conservatism principle and the asymmetric timeliness of earnings, Journal of Accounting \& Economics 24, 3-37 .

Beaver, W., 1999. Comments on 'An empirical assessment of the residual income valuation model, Journal of Accounting and Economics 26, 35-42.

Brown, S., Lo, K., Lys, T., 1999. Use of $\mathrm{R}^{2}$ in accounting research: measuring changes in value relevance over the last four decades, Journal of Accounting and Economics 28, 83-115.

Collins, D., Kothari, S.P., Shanken, J., Sloan, R., 1994. Lack of timeliness and noise as explanations for the low contemporaneous return-earnings association, Journal of Accounting and Economics 18, 289-324.

Collins, D., Maydew, E., Weiss, I., 1997. Changes in the value-relevance of earnings and book values over the past forty years, Journal of Accounting \& Economics 24, 3967.

Core, J., W. Guay, and S.P. Kothari, 2001, The Economic Dilution of Employee Stock Options: Diluted EPS for Valuation and Financial Reporting. Working paper, MIT.

Dechow, P., Hutton, A. Sloan, R., 1999. An empirical assessment of the residual income valuation model. Journal of Accounting \& Economics 26, 1-34.

Demers, E., Lev, B., 2000. A rude awakening: Internet shakeout in 2000, working paper, University of Rochester.

Economist, May 12, 2001. What's left? Don't write the new economy's obituary just yet.

Fama, E., MacBeth, J., 1973, Risk, return, and equilibrium: empirical tests, Journal of Political Economy 81, 607-636.

Fama, E., French, K., 2000, The equity premium, Working Paper number 522, Center for Research in Security Prices, University of Chicago.

Francis, J., Schipper, K., 1999. Have financial statements lost their relevance?, Journal of Accounting Research 37, 320-352.

Greene, W., 1997. Econometric Analysis. Prentice Hall, Upper Saddle River, NJ. 
Gordon, R., 2000. Does the "new economy" measure up to the great inventions of the past?, Journal of Economic Perspectives 14 (4), 49-74.

Hand, J., 2000. Profits, losses and the non-linear pricing of Internet stocks, working paper, UNC Chapel Hill.

Hayn, C., 1995. The information content of losses, Journal of Accounting \& Economics 20, 125-153.

Himmelberg, C., Hubbard, R., Palia, D., 1999. Understanding the determinants of managerial ownership and the link between ownership and performance, Journal of Financial Economics 53, 353-384.

Kothari, S P., Zimmerman, J, 1995. Price and return models, Journal of Accounting \& Economics 20, 155-192.

Lang, M., 1991. Time-varying stock price response to earnings induced by uncertainty about the time-series process of earnings. Journal of Accounting Research, 29: 229-257.

Lev, B., Zarowin, P., 1999. The boundaries of financial reporting and how to extend them, Journal of Accounting Research 37, 353-385.

Lindenberg, E.B., Ross, S.A., 1981. Tobin's q ratio and industrial organization, The Journal of Business 54, 1-32.

McConnell, J.J., Servaes, H., 1990. Additional evidence on equity ownership and corporate value, Journal of Financial Economics 27, 595-612.

Morck, R., Shleifer, A., Vishny, R., 1988. Management ownership and market valuation, an empirical analysis, Journal of Financial Economics 20, 293-315.

Newey, W., West, K., 1987. A simple, positive semi-definite heteroscedasticity and autocorrelation consistent covariance matrix. Econometrica 55, 703-708.

Ohlson, J., 1995. Earnings, book values, and dividends in equity valuation. Contemporary Accounting Research 11, 661-687.

Palepu, K., Bernard, V., Healy, P., 1996. Business Analysis and Valuation. Cincinnati, South-Western.

Rajgopal, S., Kotha, S., Venkatachalam, M., 2000. The relevance of web traffic for Internet stock prices, working paper, University of Washington.

Shiller, R., 2000. Irrational Exuberance, Princeton: Princeton University Press. 
Smithers, A., Wright, S., 2000. Valuing Wall Street: Protecting Wealth in Turbulent Markets, New York, McGraw Hill.

Tobin, J., 1969. A general equilibrium approach to monetary theory, Journal of Money, Credit and Banking 1, 15-29.

Trueman, B., Wong, F., Zhang, X., 2000. The eyeballs have it: searching for the value in Internet stocks, forthcoming, Journal of Accounting Research. 
Table 1

Panel A: Descriptive statistics for the mean market-to-book ratio, the coefficient of variation (CV) and sample size by year

\begin{tabular}{|c|c|c|c|c|c|c|c|c|c|c|c|c|}
\hline \multirow[b]{2}{*}{ Year } & \multicolumn{3}{|c|}{ All Firms } & \multicolumn{3}{|c|}{ "High-Tech } & \multicolumn{3}{|c|}{ Young } & \multicolumn{3}{|c|}{ Neither } \\
\hline & \# Firms & Mean & $\mathrm{CV}$ & \# Firms & Mean & $\mathrm{CV}$ & \# Firms & Mean & $\mathrm{CV}$ & \# Firms & Mean & CV \\
\hline 1975 & 3,190 & 1.21 & 88.5 & 369 & 1.84 & 115.4 & 95 & 2.38 & 140.6 & 2,744 & 1.12 & 83.3 \\
\hline 1976 & 3,179 & 1.20 & 81.4 & 381 & 1.81 & 145.5 & 113 & 2.73 & 146.6 & 2,716 & 1.11 & 72.8 \\
\hline 1977 & 3,169 & 1.41 & 99.3 & 393 & 2.14 & 148.8 & 140 & 4.11 & 173.0 & 2,671 & 1.24 & 81.1 \\
\hline 1978 & 3,128 & 1.53 & 111.1 & 411 & 2.41 & 137.5 & 159 & 4.45 & 144.1 & 2,596 & 1.31 & 88.1 \\
\hline 1979 & 3,115 & 1.91 & 169.0 & 420 & 3.16 & 183.8 & 199 & 7.68 & 205.1 & 2,543 & 1.47 & 126.2 \\
\hline 1980 & 3,246 & 2.90 & 188.9 & 467 & 4.91 & 202.6 & 374 & 10.64 & 199.1 & 2,480 & 1.88 & 123.5 \\
\hline 1981 & 3,450 & 1.96 & 132.8 & 533 & 3.37 & 163.3 & 601 & 3.89 & 119.6 & 2,441 & 1.41 & 111.4 \\
\hline 1982 & 3,520 & 3.44 & 191.6 & 595 & 7.44 & 243.3 & 577 & 8.60 & 197.8 & 2,502 & 2.24 & 136.5 \\
\hline 1983 & 3,846 & 2.70 & 156.7 & 740 & 4.27 & 166.1 & 715 & 4.83 & 177.5 & 2,624 & 1.98 & 104.2 \\
\hline 1984 & 3,895 & 2.56 & 134.8 & 789 & 3.83 & 185.5 & 816 & 4.12 & 126.1 & 2,541 & 2.00 & 120.2 \\
\hline 1985 & 3,882 & 3.22 & 156.6 & 801 & 4.43 & 166.4 & 610 & 6.90 & 266.5 & 2,617 & 2.40 & 129.2 \\
\hline 1986 & 4,090 & 3.76 & 164.3 & 857 & 4.98 & 157.2 & 823 & 6.72 & 188.6 & 2,585 & 2.75 & 146.4 \\
\hline 1987 & 4,202 & 2.86 & 175.3 & 905 & 4.13 & 287.4 & 906 & 4.48 & 204.5 & 2,595 & 2.24 & 150.6 \\
\hline 1988 & 4,074 & 3.02 & 170.4 & 902 & 4.27 & 191.0 & 630 & 5.92 & 243.1 & 2,695 & 2.33 & 118.7 \\
\hline 1989 & 3,990 & 2.91 & 166.6 & 887 & 3.91 & 175.6 & 491 & 6.32 & 211.1 & 2,741 & 2.33 & 136.6 \\
\hline 1990 & 3,938 & 2.85 & 171.9 & 868 & 4.09 & 173.3 & 480 & 5.07 & 203.3 & 2,715 & 2.32 & 159.3 \\
\hline 1991 & 4,092 & 3.75 & 204.6 & 933 & 5.79 & 218.2 & 629 & 6.62 & 214.0 & 2,701 & 2.82 & 182.5 \\
\hline 1992 & 4,313 & 3.28 & 144.4 & 1,006 & 4.01 & 134.2 & 844 & 4.84 & 144.4 & 2,709 & 2.69 & 145.0 \\
\hline 1993 & 4,822 & 3.33 & 130.8 & 1,150 & 4.59 & 175.1 & 1,087 & 5.11 & 177.9 & 2,882 & 2.63 & 106.4 \\
\hline 1994 & 5,092 & 3.23 & 129.1 & 1,240 & 4.81 & 140.2 & 1,139 & 4.73 & 173.0 & 3,024 & 2.53 & 108.2 \\
\hline 1995 & 5,337 & 4.20 & 153.9 & 1,386 & 6.55 & 179.4 & 1,086 & 7.50 & 216.5 & 3,242 & 2.97 & 129.5 \\
\hline 1996 & 5,844 & 3.31 & 123.6 & 1,623 & 4.71 & 151.4 & 1,398 & 4.76 & 182.2 & 3,349 & 2.57 & 104.4 \\
\hline 1997 & 5,857 & 4.01 & 136.2 & 1,682 & 5.61 & 135.5 & 1,309 & 5.98 & 180.3 & 3,336 & 3.06 & 114.5 \\
\hline 1998 & 5,453 & 3.87 & 210.6 & 1,607 & 7.75 & 290.8 & 851 & 11.24 & 406.9 & 3,317 & 2.52 & 126.7 \\
\hline 1999 & 4,960 & 5.24 & 195.2 & 1,612 & 10.87 & 195.0 & 793 & 14.03 & 315.0 & 2,988 & 2.66 & 144.7 \\
\hline Total & 103,684 & & & 22,557 & & & 16,865 & & & 69,354 & & \\
\hline \multicolumn{13}{|c|}{ Panel B: Regression of M/B on year } \\
\hline $\begin{array}{l}\text { Coefficient } \\
\text { t-stat }\end{array}$ & $\begin{array}{c}0.12 \\
(7.97) \\
\end{array}$ & & & $\begin{array}{c}0.20 \\
(4.09) \\
\end{array}$ & & & $\begin{array}{c}0.18 \\
(1.87) \\
\end{array}$ & & & $\begin{array}{c}0.07 \\
(6.76) \\
\end{array}$ & & \\
\hline
\end{tabular}


The coefficient of variation (CV) is the sample standard deviation divided by the sample mean. Firms are categorized as 'High-Tech' following the 3-digit SIC code classification in Francis and Schipper (1999). A firm is considered 'Young' if that firm was public for 2 years or less, based on its CRSP starting date. 
Table 2

Results of by-year regressions

\begin{tabular}{|c|c|c|c|c|c|c|c|c|}
\hline \multirow[b]{3}{*}{ Independent Variable } & \multicolumn{6}{|c|}{ "Dependent Variable: Market-to-book equity } & \multirow{2}{*}{\multicolumn{2}{|c|}{ Neither High, Young }} \\
\hline & \multicolumn{2}{|c|}{ All Firms } & \multicolumn{2}{|c|}{ High-Tech Firms } & \multicolumn{2}{|c|}{ Young Firms } & & \\
\hline & Estimate & $>0$ & Estimate & $>0$ & Estimate & $>0$ & Estimate & $>0$ \\
\hline INTERCEPT & $\begin{array}{c}0.10 \\
(0.74)\end{array}$ & 16 & $\begin{array}{c}0.13 \\
(0.32)\end{array}$ & 14 & $\begin{array}{c}-1.32 \\
(-3.23)\end{array}$ & 7 & $\begin{array}{c}0.30 \\
(3.12)\end{array}$ & 20 \\
\hline 1/BVE & $\begin{array}{c}0.04 \\
(11.68)\end{array}$ & 25 & $\begin{array}{c}0.06 \\
(7.26)\end{array}$ & 25 & $\begin{array}{c}0.12 \\
(3.24)\end{array}$ & 25 & $\begin{array}{c}0.03 \\
(11.94)\end{array}$ & 25 \\
\hline POS_NI/BVE & $\begin{array}{c}9.53 \\
(13.85)\end{array}$ & 25 & $\begin{array}{c}10.03 \\
(19.77)\end{array}$ & 25 & $\begin{array}{l}13.06 \\
(8.71)\end{array}$ & 25 & $\begin{array}{c}8.46 \\
(12.68)\end{array}$ & 25 \\
\hline NEG_NI/BVE & $\begin{array}{c}-1.62 \\
(-12.46)\end{array}$ & 1 & $\begin{array}{c}-2.48 \\
(-11.02)\end{array}$ & 2 & $\begin{array}{c}-0.69 \\
(-1.09)\end{array}$ & 9 & $\begin{array}{c}-1.43 \\
(-10.08)\end{array}$ & 0 \\
\hline RND/BVE & $\begin{array}{c}7.02 \\
(8.13)\end{array}$ & 25 & $\begin{array}{c}6.33 \\
(3.94)\end{array}$ & 24 & $\begin{array}{l}13.24 \\
(4.92)\end{array}$ & 24 & $\begin{array}{c}5.69 \\
(10.78)\end{array}$ & 25 \\
\hline ADVERT/BVE & $\begin{array}{c}0.82 \\
(1.57)\end{array}$ & 15 & $\begin{array}{c}0.31 \\
(0.31)\end{array}$ & 11 & $\begin{array}{c}1.67 \\
(0.94)\end{array}$ & 15 & $\begin{array}{c}0.88 \\
(2.62)\end{array}$ & 20 \\
\hline CAP_EX/BVE & $\begin{array}{l}1.32 \\
(7.3)\end{array}$ & 24 & $\begin{array}{c}2.03 \\
(4.32)\end{array}$ & 22 & $\begin{array}{c}3.19 \\
(2.95)\end{array}$ & 23 & $\begin{array}{l}0.95 \\
(11)\end{array}$ & 25 \\
\hline SALES_GR/BVE & $\begin{array}{c}0.36 \\
(2.84)\end{array}$ & 19 & $\begin{array}{c}0.93 \\
(2.61)\end{array}$ & 22 & $\begin{array}{c}0.79 \\
(1.34)\end{array}$ & 16 & $\begin{array}{c}0.20 \\
(2.49)\end{array}$ & 19 \\
\hline SG_MISS & $\begin{array}{c}2.56 \\
(5.89) \\
\end{array}$ & 25 & $\begin{array}{c}6.28 \\
(2.98) \\
\end{array}$ & 23 & $\begin{array}{c}2.89 \\
(2.48) \\
\end{array}$ & 22 & $\begin{array}{c}0.62 \\
(2.68) \\
\end{array}$ & 14 \\
\hline Total Observations & 103,684 & & 22,557 & & 16,865 & & 69,354 & \\
\hline Average R-squared value & $35 \%$ & & $36 \%$ & & $43 \%$ & & $33 \%$ & \\
\hline
\end{tabular}


Estimates are the mean coefficients from 25 annual estimations of the following regression:

$M V E / B V E=\alpha_{0}+\alpha_{1}(1 / B V E)+\alpha_{2}\left(P O S \_N I / B V E\right)+\alpha_{3}\left(N E G \_N I / B V E\right)+\alpha_{4}(R N D / B V E)+\alpha_{5}(A D V E R T / B V E)+\alpha_{6}\left(C A P \_E X / B V E\right)$

$+\alpha_{7}\left(S A L E S \_G R / B V E\right)+\alpha_{8} S G \_M I S S+\varepsilon$

Where MVE = Market value of equity; BVE = Book value of equity; POS_NI = Net Income Before Extraordinary Items/Book value of equity if Net Income Before Ex. Items $>0,0$ otherwise; NEG_NI = Net Income Before Extraordinary Items if Net Income Before Ex. Items $\leq$ 0, RND = R\&D Expenditures; ADVERT = Advertising Expenditures; CAP_EX = Capital Expenditures; SALES_GR = One year change in real sales dollars (adjusted for changes in CPI) if available, and zero otherwise; SG_MISS = Dummy variable equal to one if previous year sales unavailable and zero otherwise. The variable (1/BVE) is expressed in constant 1983 dollars using the CPI deflator.

T-statistics are based on standard errors corrected for autocorrelation by the method of Newey and West (1987), with a lag of 6. 


\section{Table 3}

Panel A: Pattern of $\boldsymbol{R}^{2}$ values from annual regressions

\begin{tabular}{|c|c|c|c|c|}
\hline Year & All Firms & High-Tech & Young & Neither \\
\hline 1975 & $31 \%$ & $39 \%$ & $47 \%$ & $30 \%$ \\
\hline 1976 & $36 \%$ & $43 \%$ & $52 \%$ & $37 \%$ \\
\hline 1977 & $40 \%$ & $32 \%$ & $47 \%$ & $38 \%$ \\
\hline 1978 & $35 \%$ & $33 \%$ & $36 \%$ & $31 \%$ \\
\hline 1979 & $34 \%$ & $29 \%$ & $53 \%$ & $28 \%$ \\
\hline 1980 & $42 \%$ & $32 \%$ & $71 \%$ & $34 \%$ \\
\hline 1981 & $37 \%$ & $24 \%$ & $29 \%$ & $35 \%$ \\
\hline 1982 & $41 \%$ & $73 \%$ & $54 \%$ & $37 \%$ \\
\hline 1983 & $40 \%$ & $52 \%$ & $53 \%$ & $38 \%$ \\
\hline 1984 & $37 \%$ & $44 \%$ & $36 \%$ & $37 \%$ \\
\hline 1985 & $36 \%$ & $36 \%$ & $45 \%$ & $25 \%$ \\
\hline 1986 & $37 \%$ & $39 \%$ & $36 \%$ & $26 \%$ \\
\hline 1987 & $39 \%$ & $43 \%$ & $36 \%$ & $35 \%$ \\
\hline 1988 & $36 \%$ & $42 \%$ & $32 \%$ & $32 \%$ \\
\hline 1989 & $34 \%$ & $32 \%$ & $39 \%$ & $33 \%$ \\
\hline 1990 & $35 \%$ & $39 \%$ & $44 \%$ & $32 \%$ \\
\hline 1991 & $38 \%$ & $32 \%$ & $48 \%$ & $39 \%$ \\
\hline 1992 & $43 \%$ & $30 \%$ & $39 \%$ & $44 \%$ \\
\hline 1993 & $35 \%$ & $35 \%$ & $47 \%$ & $36 \%$ \\
\hline 1994 & $39 \%$ & $37 \%$ & $53 \%$ & $36 \%$ \\
\hline 1995 & $30 \%$ & $29 \%$ & $42 \%$ & $29 \%$ \\
\hline 1996 & $31 \%$ & $29 \%$ & $41 \%$ & $31 \%$ \\
\hline 1997 & $32 \%$ & $25 \%$ & $29 \%$ & $33 \%$ \\
\hline 1998 & $24 \%$ & $20 \%$ & $24 \%$ & $26 \%$ \\
\hline 1999 & $22 \%$ & $19 \%$ & $34 \%$ & $27 \%$ \\
\hline Mean & $35 \%$ & $36 \%$ & $43 \%$ & $33 \%$ \\
\hline Median & $36 \%$ & $33 \%$ & $42 \%$ & $33 \%$ \\
\hline Minimum & $22 \%$ & $19 \%$ & $24 \%$ & $25 \%$ \\
\hline Maximum & $43 \%$ & $73 \%$ & $71 \%$ & $44 \%$ \\
\hline
\end{tabular}

$R^{2}$ values are based on the following regression, performed annually from 1975-1999:

$M V E / B V E=\alpha_{0}+\alpha_{1}(1 / B V E)+\alpha_{2}\left(P O S \_N I / B V E\right)+\alpha_{3}\left(N E G \_N I / B V E\right)+\alpha_{4}(R N D / B V E)+\alpha_{5}(A D V E R T / B V E)$

$$
+\alpha_{6}\left(C A P \_E X / B V E\right)+\alpha_{7}\left(S A L E S \_G R / B V E\right)+\alpha_{8} S G_{-} M I S S+\varepsilon
$$

where the variables are defined as in Table 2. 
Table 3 (continued)

Panel B: Regression of $\boldsymbol{R}^{2}$ on year

\begin{tabular}{lcccc}
\hline \hline & All Firms & High-Tech & Young & Neither \\
\hline Year & -0.34 & -0.62 & -0.60 & -0.10 \\
& $(-1.63)$ & $(-2.02)$ & $(-3.21)$ & $(-0.81)$ \\
& & & & \\
\hline \hline
\end{tabular}

Panel C: Regression of $\boldsymbol{R}^{2}$ on year and CV of market-to-book

\begin{tabular}{lcccc}
\hline \hline & All Firms & High-Tech & Young & Neither \\
\hline Year & -0.38 & -0.70 & -0.56 & -0.11 \\
& $(-2.23)$ & $(-2.53)$ & $(-1.75)$ & $(-0.98)$ \\
& & & & \\
CV & 0.02 & 0.06 & -0.01 & 0.01 \\
& $(0.47)$ & $(0.95)$ & $(-0.17)$ & $(0.23)$ \\
\hline \hline
\end{tabular}

Panel D: Regression of $\boldsymbol{R}^{2}$ on year, CV of market-to-book, and a dummy variable for the 1996-1999 NEP

\begin{tabular}{lcccc}
\hline \hline & All Firms & High-Tech & Young & Neither \\
\hline Year & -0.06 & -0.35 & -0.35 & 0.14 \\
& $(-0.48)$ & $(-1.57)$ & $(-1.04)$ & $(1.35)$ \\
CV & & & & \\
& 0.01 & 0.06 & 0.00 & -0.03 \\
& $(0.19)$ & $(1.00)$ & $(0.09)$ & $(-0.76)$ \\
NEP* & & & & \\
& -9.27 & -10.99 & -8.58 & -6.23 \\
& $(-4.42)$ & $(-2.86)$ & $(-2.30)$ & $(-3.47)$ \\
\hline \hline
\end{tabular}

The coefficient of variation (CV) is the annual sample standard deviation of the market-to-book ratio divided by its annual sample mean. T-statistics are based on standard errors corrected for autocorrelation by the method of Newey and West (1987), with a lag of 6.

*NEP represents a dummy variable equal to 1 if the year is $1996-1999$. 
Table 4

Loss in coefficient explanatory power from out of sample predictions

Panel A: Predictions based on prior 4-year periods ${ }^{(1)}$

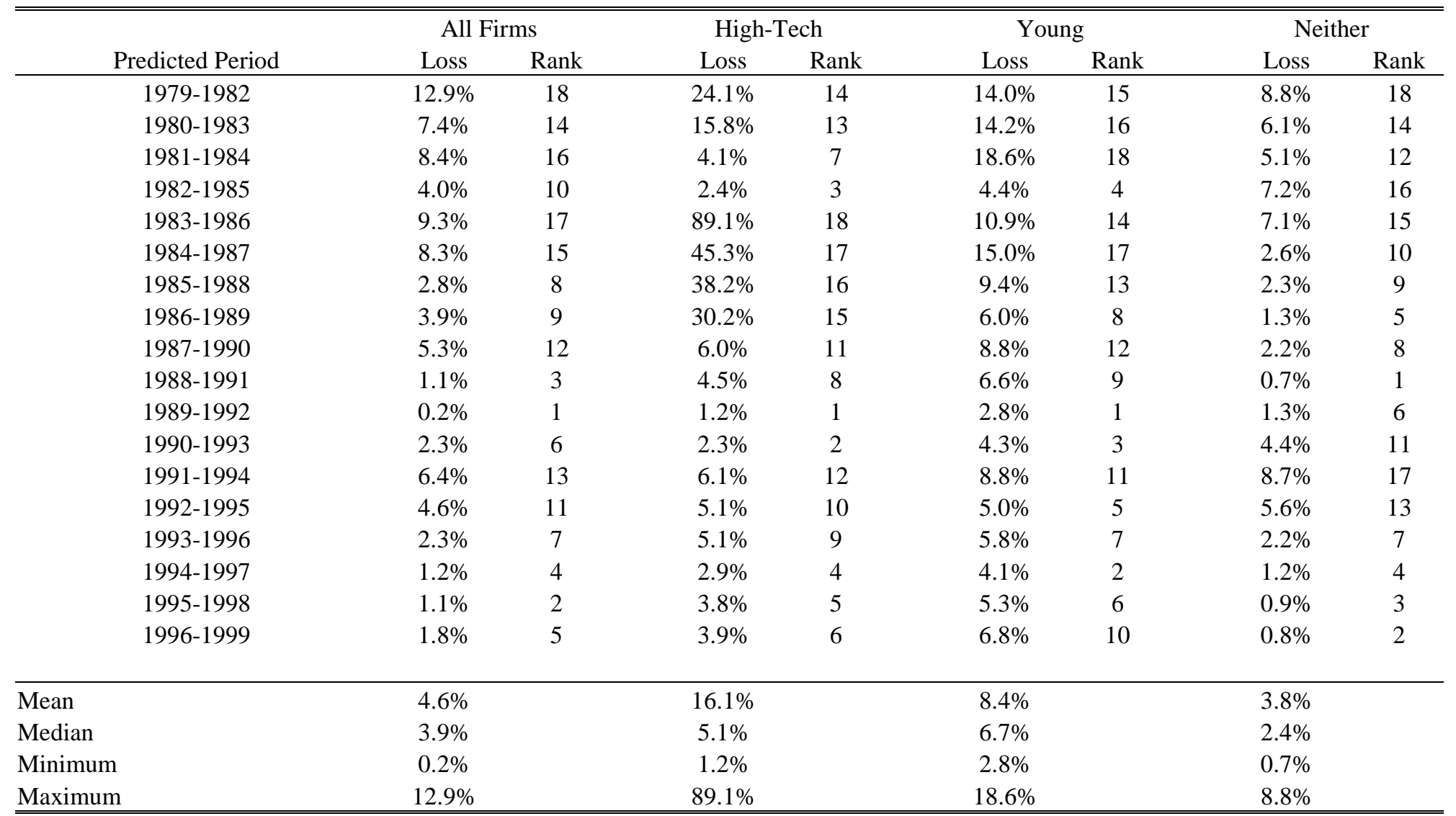


Table 4 (continued)

Loss in coefficient explanatory power from out of sample predictions

Panel B: Predictions based all 21 years outside of prediction period ${ }^{(2)}$

\begin{tabular}{|c|c|c|c|c|c|c|c|c|c|}
\hline \multirow{2}{*}{\multicolumn{2}{|c|}{ Predicted Period }} & \multicolumn{2}{|c|}{ All } & \multicolumn{2}{|c|}{ High } & \multicolumn{2}{|c|}{ Young } & \multicolumn{2}{|c|}{ Neither } \\
\hline & & Loss & Rank & Loss & Rank & Loss & Rank & Loss & Rank \\
\hline & $1975-1978$ & $110.2 \%$ & 22 & $68.8 \%$ & 22 & $56.7 \%$ & 22 & $106.2 \%$ & 22 \\
\hline & 1976-1979 & $52.6 \%$ & 21 & $37.6 \%$ & 21 & $32.4 \%$ & 21 & $73.7 \%$ & 21 \\
\hline & $1977-1980$ & $16.0 \%$ & 20 & $7.6 \%$ & 14 & $18.0 \%$ & 20 & $33.6 \%$ & 20 \\
\hline & $1978-1981$ & $10.8 \%$ & 19 & $4.0 \%$ & 6 & $14.0 \%$ & 18 & $27.5 \%$ & 19 \\
\hline & 1979-1982 & $5.9 \%$ & 17 & $19.8 \%$ & 20 & $8.1 \%$ & 15 & $8.2 \%$ & 18 \\
\hline & 1980-1983 & $4.0 \%$ & 11 & $16.1 \%$ & 18 & $5.0 \%$ & 6 & $3.0 \%$ & 8 \\
\hline & 1981-1984 & $2.0 \%$ & 7 & $11.0 \%$ & 16 & $7.8 \%$ & 14 & $2.2 \%$ & 6 \\
\hline & $1982-1985$ & $1.3 \%$ & 4 & $5.9 \%$ & 11 & $3.9 \%$ & 2 & $1.1 \%$ & 1 \\
\hline & 1983-1986 & $1.0 \%$ & 2 & $4.0 \%$ & 5 & $7.5 \%$ & 13 & $2.0 \%$ & 4 \\
\hline & 1984-1987 & $0.9 \%$ & 1 & $2.3 \%$ & 2 & $8.2 \%$ & 16 & $1.2 \%$ & 3 \\
\hline & 1985-1988 & $1.0 \%$ & 3 & $4.7 \%$ & 8 & $4.5 \%$ & 5 & $2.3 \%$ & 7 \\
\hline & 1986-1989 & $3.3 \%$ & 9 & $9.9 \%$ & 15 & $6.9 \%$ & 12 & $4.3 \%$ & 10 \\
\hline & 1987-1990 & $10.3 \%$ & 18 & $17.0 \%$ & 19 & $17.1 \%$ & 19 & $7.5 \%$ & 16 \\
\hline & 1988-1991 & $3.7 \%$ & 10 & $15.5 \%$ & 17 & $6.6 \%$ & 10 & $2.1 \%$ & 5 \\
\hline & 1989-1992 & $1.3 \%$ & 5 & $7.6 \%$ & 13 & $5.2 \%$ & 8 & $1.1 \%$ & 2 \\
\hline & 1990-1993 & $1.5 \%$ & 6 & $1.9 \%$ & 1 & $4.2 \%$ & 4 & $3.2 \%$ & 9 \\
\hline & 1991-1994 & $3.3 \%$ & 8 & $4.2 \%$ & 7 & $3.8 \%$ & 1 & $6.0 \%$ & 13 \\
\hline & 1992-1995 & $4.4 \%$ & 12 & $3.4 \%$ & 3 & $3.9 \%$ & 3 & $6.8 \%$ & 14 \\
\hline & 1993-1996 & $4.5 \%$ & 13 & $5.0 \%$ & 9 & $5.2 \%$ & 7 & $5.8 \%$ & 12 \\
\hline & 1994-1997 & $5.0 \%$ & 16 & $6.2 \%$ & 12 & $5.7 \%$ & 9 & $7.2 \%$ & 15 \\
\hline & 1995-1998 & $4.6 \%$ & 14 & $3.4 \%$ & 4 & $6.6 \%$ & 11 & $7.5 \%$ & 17 \\
\hline & 1996-1999 & $4.8 \%$ & 15 & $5.8 \%$ & 10 & $10.0 \%$ & 17 & $5.6 \%$ & 11 \\
\hline$\overline{\text { Mean }}$ & & $11.5 \%$ & & $11.9 \%$ & & $11.0 \%$ & & $14.5 \%$ & \\
\hline Median & & $4.2 \%$ & & $6.0 \%$ & & $6.7 \%$ & & $5.7 \%$ & \\
\hline Minimum & & $0.9 \%$ & & $1.9 \%$ & & $3.8 \%$ & & $1.1 \%$ & \\
\hline Maximum & & $110.2 \%$ & & $68.8 \%$ & & $56.7 \%$ & & $106.2 \%$ & \\
\hline
\end{tabular}


(1) The change from 4-year prediction is calculated as follows:

- An weighted least squares (WLS) estimation of Eq. (1) is performed on the Predicted period, yielding a Residual Sum of Squares (RSS).

- The weights for each observation in a sample-year are inversely proportional to the number of observations in that year.

- A WLS estimation of Eq. (1) is performed on the immediately preceding 4-year period and the coefficient estimates from that regression are used to estimate the Market/Book value in the predicted period. For example, use the coefficient estimates from an WLS regression in 1991-1994 to estimate Market/Book values in 1995-1998. This estimation yields a predicted Residual Sum of Squares (PSS).

- The loss in explanatory power is calculated as $\frac{P S S-R S S}{\sum\left(y_{i t}-\bar{y}\right)^{2}}$

(2) The loss from 21-year prediction is calculated in a manner similar to (2), but instead of using the immediately preceding 4-year period for estimating the coefficients, every year outside of the 4-year predicted period is used. For example, in order to estimate the Market/Book values for the period 1991-1994, we use an WLS estimation of Eq. (1) including all firm-year observations from 1975-1990 and 1995-1999. 


\section{Table 5 \\ Young, Loss firms \\ Loss in coefficient explanatory power from out of sample predictions}

\begin{tabular}{|c|c|c|c|c|c|}
\hline \multirow{2}{*}{\multicolumn{2}{|c|}{ Predicted Period }} & \multicolumn{2}{|c|}{ 4-year ${ }^{(1)}$} & \multicolumn{2}{|c|}{16 -year ${ }^{(2)}$} \\
\hline & & Loss & Rank & Loss & Rank \\
\hline & $1980-1983$ & & & $19.6 \%$ & 9 \\
\hline & 1981-1984 & & & $106.8 \%$ & 17 \\
\hline & $1982-1985$ & & & $25.1 \%$ & 11 \\
\hline & $1983-1986$ & & & $25.6 \%$ & 12 \\
\hline & 1984-1987 & $29.7 \%$ & 8 & $10.9 \%$ & 7 \\
\hline & $1985-1988$ & $32.1 \%$ & 9 & $10.6 \%$ & 6 \\
\hline & 1986-1989 & $135.7 \%$ & 13 & $26.4 \%$ & 13 \\
\hline & $1987-1990$ & $110.0 \%$ & 11 & $22.9 \%$ & 10 \\
\hline & 1988-1991 & $110.1 \%$ & 12 & $57.6 \%$ & 16 \\
\hline & 1989-1992 & $22.5 \%$ & 7 & $27.2 \%$ & 14 \\
\hline & $1990-1993$ & $20.8 \%$ & 6 & $18.6 \%$ & 8 \\
\hline & 1991-1994 & $65.7 \%$ & 10 & $40.2 \%$ & 15 \\
\hline & $1992-1995$ & $12.1 \%$ & 4 & $10.1 \%$ & 5 \\
\hline & $1993-1996$ & $9.7 \%$ & 2 & $8.1 \%$ & 3 \\
\hline & 1994-1997 & $2.0 \%$ & 1 & $5.8 \%$ & 2 \\
\hline & 1995-1998 & $11.8 \%$ & 3 & $8.1 \%$ & 4 \\
\hline & 1996-1999 & $16.7 \%$ & 5 & $5.3 \%$ & 1 \\
\hline Mean & & $44.5 \%$ & & $25.2 \%$ & \\
\hline Median & & $22.5 \%$ & & $19.6 \%$ & \\
\hline Minimum & & $2.0 \%$ & & $5.3 \%$ & \\
\hline Maximum & & $135.7 \%$ & & $106.8 \%$ & \\
\hline
\end{tabular}

(1) The change from 4-year prediction is calculated as follows:

- An weighted least squares (WLS) estimation of Eq. (1) is performed on the Predicted period, yielding a Residual Sum of Squares (RSS).

- The weights for each observation in a sample-year are inversely proportional to the number of observations in that year.

- A WLS estimation of Eq. (1) is performed on the immediately preceding 4-year period and the coefficient estimates from that regression are used to estimate the Market/Book value in the predicted period. For example, use the coefficient estimates from an WLS regression in 19911994 to estimate Market/Book values in 1995-1998. This estimation yields a predicted Residual Sum of Squares (PSS).

- The loss in explanatory power is calculated as $\frac{P S S-R S S}{\sum\left(y_{i t}-\bar{y}\right)^{2}}$

(2) The loss from 16-year prediction is calculated in a manner similar to (2), but instead of using the immediately preceding 4-year period for estimating the coefficients, every year outside of the 4-year predicted period is used. For example, in order to estimate the Market/Book values for the period 1991-1994, we use an WLS estimation of Eq. (1) including all firm-year observations from 19801990 and 1995-1999. 